\title{
PBL BERBANTUAN MEDIA AUDIOVISUAL DAN TIPE KEPRIBADIAN DALAM PEMBELAJARAN IPS
}

\author{
Ni Made Astiti ${ }^{1}$, Sukadi², I Gede Astra Wesnawa ${ }^{3}$ \\ Program Studi Pendidikan IPS Universitas Pendidikan Ganesha Singaraja \\ e-mail: madeastiti22@gmail.com¹, adhys_pkn@yahoo.com², gede astrawesnawa@yahoo.com³
}

\begin{abstract}
Abstrak
Tujuan utama penelitian ini adalah untuk mengetahui pengaruh model pembelajaran berbasis masalah berbantuan media audio visual terhadap hasil belajar siswa ditinjau dari tipe kepribadian. Penelitian ini dilakukan pada siswa kelas VII SMP Negeri 6 Denpasar, dengan menggunkan desain treatmen by level $2 \times 2$. Ada dua jenis instrument yang digunakan untuk menjaring data, yaitu: tes tipe kepribadian dan tes hasil belajar IPS. Data hasil penelitian dianalis dengan menggunakan ANAVA. Hasil penelitian ini menunjukkan bahwa 1) terdapat interaksi antara model pembelajaran dengan tipe kepribadian dalam pengaruhnya terhadap hasil belajar IPS dan 2) untuk siswa yang memiliki tipe kepribadian ekstrovert lebih cocok dengan model pembelajaran berbasis masalah berbantuan media audiovisual, sedangkan untuk siswa yang memiliki tipe kepribadian introvert lebih cocok dengan model pembelajaran konvensional.
\end{abstract}

Kata kunci: PBL, media audiovisual, tipe kepribadian, hasil belajar

\section{Abstract}

The main purpose of this study is to determine the effect of problem learning-based model of media audio-visual assisted on student learning outcomes in terms of personality type. This research was conducted on the seventh grade students of SMP Negeri 6 Denpasar, by using the design of treatment by level $2 \times 2$. There are two types of instruments used to capture data, namely: personality type tests and IPS learning achievement test. The data of the research were analyzed by using two-ways ANAVA. The results of this study indicate that 1) there is an interaction effect between the learning model and the personality type in the IPS learning outcomes and 2) for the students who having extroverted personality types better suited to the media problem-based learning model assisted media audiovisual, whereas for students with introverted personality types more suited to conventional learning model.

Keywords : PBL, audiovisual media, personality types, leraning achievement

\section{PENDAHULUAN}

Pendidikan adalah usaha sadar dan terencana untuk mewujudkan suasana belajar dan proses pembelajaran agar peserta didik secara aktif mengembangkan potensi dirinya untuk memiliki kekuatan spiritual keagamaan, pengendalian diri, kepribadian, kecerdasan, akhlak mulia, serta keterampilan yang diperlukan dirinya, masyarakat, bangsa dan negara (UU Sisdiknas, 2003). Menurut Rasmianti (2013), pendidikan merupakan suatu kebutuhan yang harus dipenuhi dalam kehidupan bermasyarakat, berbangsa dan bernegara. Maju mundurnya suatu bangsa banyak ditentukan oleh kreativitas pendidikan bangsa itu sendiri. Oleh karena itu, peranan pendidikan sangatlah penting, sebab pendidikan merupakan lembaga yang berusaha membangun masyarakat dan watak bangsa secara berkesinambungan, yaitu membina mental rasio, intelek dan kepribadian dalam rangka membentuk manusia seutuhnya.

Pendidikan bertujuan membentuk sumberdaya manusia (SDM) yang berkualitas, bernalar tinggi, terbuka, cerdas dan mampu memproses informasi sangat dibutuhkan dalam menghadapi perkembangan IPTEK. Kemajuan teknologi yang semakin pesat tidak lepas dari 
perkembangan bidang IImu Pengetahuan Sosial (IPS) sebagai ilmu dasar dalam mempelajari ekonomi. Usaha meningkatkan sumber daya manusia (SDM) dalam bidang IPS menjadi tugas penting bagi pemerintah khususnya dalam bidang pendidikan. Mutu pendidikan yang tinggi dalam pendidikan IPS sangat diperlukan untuk menciptakan SDM yang mampu bersaing di dunia global.

Ada beberapa komponen yang berpengaruh dalam proses belajar mengajar, yang sering disebut dengan faktor eksternal dan faktor internal. Faktor eksternal diantaranya adalah guru, sarana dan prasarana, metode pembelajaran, kurikulum dan lingkungan belajar yang efektif dan menyenangkan. Sedangkan Faktor internal diantaranya, motivasi, gaya belajar, tipe kepribadian, kecerdasan, gaya berbipikir dan lain sebagainya. Antara komponen yang satu dengan yang lain harus saling mendukung dalam mewujudkan tujuan pendidikan yang diharapkan. Guru dituntut untuk dapat melakukan usaha-usaha dalam menumbuhkan dan membangkitkan minat belajar siswanya dalam pembelajaran. Seorang guru tidak hanya cukup menyampaikan materi pelajaran semata, akan tetapi guru juga harus bisa menciptakan suasana belajar yang baik dan menyenangkan. Guru juga harus tepat dalam pemilihan metode dan strategi yang digunakan dalam proses pembelajaran yang sesuai dengan materi dan keadaan siswa.

Kaitannya dengan faktor eksternal, penggunaan model pembelajaran dalam suatu proses pembelajaran mempunyai pengaruh yang besar dalam tercapainya tujuan pembelajaran. Penggunaan model pembelajaran yang tepat tentunya berpengaruh terhadap hasil belajar siswa. Untuk mewujudkan proses pembelajaran yang menarik dan memnyenangkan tentunya tidaklah mudah seperti yang dibayangkan. Begitu pula yang terjadi pada pembelajaran IPS. Tidak dapat dipungkiri bahwa hasil belajar IPS siswa selama ini masih tergolong rendah. Rendahnya hasil belajar ini disinyalir disebabkan oleh masih dominannya skill menghafal daripada skill memproses sendiri pemahaman suatu materi pembelajaran.

Selama ini, minat belajar siswa terhadap mata pelajaran IPS masih tergolong sangat rendah. Hal ini dapat dilihat pada sikap siswa selama mengikuti proses pembelajaran tidak fokus dan ramai sendiri. Bahkan ada sebagian siswa menganggap mata pelajaran IPS tidak begitu penting, dibandingkan suadara tirinya MIPA, dikarenakan tidak masuk pada mata pelajaran yang diujikan pada Ujian Nasional (UN). Tentunya minat yang rendah tersebut akan bermuara pada rendahnya hasil belajar siswa. Faktor model pembelajaran yang digunakan guru dalam menyampaikan materi juga berpengaruh terhadap hasil belajar IPS siswa. Model konvensional, seperti menjelaskan materi secara abstrak, hafalan materi dan ceramah dengan komunikasi satu arah, yang aktif masih didominasi oleh pengajar, sedangkan siswa biasanya hanya memfokuskan penglihatan dan pendengaran. Kondisi pembelajaran seperti inilah yang mengakibatkan siswa kurang aktif dan pembelajaran yang dilakukan kurang efektif. Hal ini sesuai dengan pendapat Sanjaya (2008) bahwa proses pembelajaran di dalam kelas hanya diarahkan kepada kemampuan anak untuk menghafal informasi dan tidak diarahkan untuk membangun dan mengembangkan karakter serta potensi yang dimiliki.

Model pembelajaran yang masih terlalu didominasi peran guru (teacher oriented) kurang memberikan kesempatan pada siswa untuk belajar aktif dalam pembelajaran di kelas. Penggunaan metode ceramah merupakan pilihan utama dalam pembelajaran. Dalam metode ceramah, guru menyampaikan informasi dan pengetahuan secara lisan kepada siswa, sehingga siswa cenderung pasif dalam pembelajaran karena hanya mencatat dan mendengarkan. Kondisi seperti ini yang terkadang membuat proses pembelajaran kurang menarik dan berpengaruh pada hasil belajar siswa.

Guru dituntut untuk meningkatkan kualitas proses belajar mengajar sehingga nantinya diharapkan dapat meningkatkan hasil belajar peserta didik. Guru harus memiliki inovasi dalam peningkatan mutu pendidikan. Peningkatan proses belajar tersebut dapat dilakukan dengan pendekatan, strategi, model, atau metode pembelajaran inovatif. Meskipun guru sudah merasa sangat nyaman dengan model pembelajaran konvensional, namun sangat diharapkan guru dapat mengurangi bahkan meninggalkan model pembelajaran konvensional yang dianggap sangat tradisional. Permasalahan yang dikaji hendaknya 
merupakan permasalahan konstektual yang ditemukan oleh peserta didik dalam kehidupan sehari-hari. Model pembelajaran yang bertujuan untuk mengaktifkan peserta didik dengan penyelesaian permasalahan dunia nyata (real world problem) dan penyampaiannya dilakukan dengan cara menyajikan suatu permasalahan adalah model pembelajaran problem based learning (Sani, 2014).

Model pembelajaran problem based learning atau pembelajaran berbasis masalah adalah suatu model pembelajaran yang menggunakan masalah dunia nyata sebagai suatu konteks bagi peserta didik untuk belajar tentang cara berpikir kritis dan keterampilan pemecahan masalah, serta untuk memperoleh pengetahuan dan konsep yang esensial dari materi pelajaran. Menurut Sani (2014), problem based learning (PBL) merupakan pembelajaran yang penyampaiannya dilakukan dengan cara menyajikan suatu permasalahan, mengajukan pertanyaan-pertanyaan, memfasilitasi penyelidikan, dan membuka dialog. Permasalahan yang dikaji dalam model PBL sebaiknya diajukan oleh peserta didik, namun guru juga dapat membantu mengidentifikasikan permasalahan atau mengajukan permasalahan kontekstual yang dikaji jika peserta didik kesulitan mengidentifikasikan permasalahan.

Menurut Lestari (2014), pada prinsipnya dalam model pembelajaran PBL peserta didik sendirilah yang secara aktif mencari jawaban atas masalah-masalah yang diberikan guru. Dalam hal ini guru lebih banyak sebagai mediator dan fasilitator untuk membantu peserta didik dalam mengkontruksi pengetahuan mereka secara efektif. Dengan model pembelajaran PBL peserta didik dapat memahami masalah dalam kehidupan sehari-hari, mengembangkan pengetahuannya, memahami hakikat belajar sebagai cara berpikir bukan sekedar mengerti pembelajaran oleh guru berdasarkan buku teks serta peserta didik dapat terangsang untuk belajar secara kontinu. Akan tetapi, model pembelajaran PBL memiliki kelemahan yakni pada proses pembelajarannya membutuhkan waktu pembelajaran yang cukup lama, karena permasalahan yang dibahas dapat berupa permasalahan yang membutuhkan penguasaan atau kerja sama dari beberapa mata pelajaran. Salah satu cara yang bisa digunakan untuk mengatasi kelaman tersebut adalah dengan menggunakan bantuan media audiovisual (Sani, 2014).

Media audiovisual adalah media yang mempunyai unsur suara dan unsur gambar. Jenis media ini mempunyai kemampuan yang lebih baik, karena meliputi kedua jenis media auditif (mendengar) dan visual (melihat). Media Audiovisual merupakan sebuah alat bantu audiovisual yang berarti bahan atau alat yang dipergunakan dalam situasi belajar untuk membantu tulisan dan kata yang diucapkan dalam menularkan pengetahuan, sikap, dan ide. Penggunaan media proses belajar mengajar merupakan salah solusi yang dapat memudahkan tenaga pendidik dalam menyampaikan materi yang disampaikan. Media pembelajaran adalah segala sesuatu yang dapat digunakan untuk menyalurkan pesan (bahan ajar) sehingga dapat merangsang perhatian, minat, pikiran dan perasaaan peserta didik dalam kegiatan belajar untuk mencapai tujuan pembelajaran tertentu. Harjanto (2005) menyatakan media mempunyai manfaat di mana bahan pengajaran akan lebih jelas maknanya sehingga dapat dipahami oleh peserta didik. Hal ini seharusnya diperhatikan oleh tenaga pendidik untuk membangun proses belajar mengajar yang menyenangkan, dan meningkatkan pemahaman peserta didik. Hal ini sesui dengan hasil penelitian Supriadi, dkk (2013) yang menunjukkan bahwa hasil belajar IPS siswa yang mengikuti model pembelajaran berbasis masalah berbantuan audiovisual lebih baik daripada hasil belajar IPS siswa yang mengikuti model pembelajaran konvensional.

Tentunya hasil belajar siswa tidak mutlak dipengaruhi oleh faktor internal beruapa model pembelajaran dan media yang digunakan oleh guru saja. Ada faktor lain, yaitu faktor internal yang juga mempengaruhi hasil belajar siswa. Faktor internal tersebut seperti: inteligensi, tipe kepribadian, bakat, minat, motivasi, sikap, dan lain-lain. Dalam penelitian ini yang dibahas adalah bakat tipe kepribadian siswa kaitannya dengan hasil belajar IPS. Menurut Ulya (2016), hal lain yang tidak dapat diabaikan yaitu dalam menerapkan model pembelajaran perlu mempertimbangkan tipe kepribadian peserta didik. Kepribadian adalah suatu unsur yang terdapat dalam diri atau individu. Kepribadian ini mencerminkan bagaimana seseorang bertingkah laku dan berpikir. Kepribadian merupakan suatu sistem diri 
dalam diri individu, sebagai wujud dari pengorganisasian dalam dirinya, yang mana sistem tersebut bersifat dinamis, mengikuti keadaan mental seseorang, dan bersifat unik atau khas. Eysenck seperti dikutip Ulya (2016) membagi tipe kepribadian menjadi dua, yakni extrovert (cenderung berorientasi ke luar) dan introvert (cenderung berorientasi ke dalam). Penggunaan model pembelajaran yang bersifat pasif seperti model pembelajaran konvensional kemungkinan besar memberikan pengaruh terhadap peningkatan hasil belajar peserta didik introvert, karena peserta didik introvert cenderung bersifat pasif dan lebih suka bekerja sendirian. Sedangkan penggunaan model pembelajaran yang bersifat aktif memberikan pengaruh terhadap hasil belajar peserta didik extrovert, karena peserta didik extrovert cenderung bersifat aktif dan lebih kooperatif.

\section{METODE}

Beberapa faktor yang dilibatkan dalam penelitian ini adalah model pembelajaran dan tipe kepribadian yang difungsikan sebagai variabel bebas, sedangkan hasil belajar IPS sebagai variabel terikat. Penelitian ini bersifat desian eksperimen semu dengan rancangan treatmen by lever $2 \times 2$. Populasi dalam penelitian ini adalah seluruh siswa kelas VII SMP Negeri 6 Denpasar tahun ajaran 2017/2018 dan melibatkan sampel sebanyak 100 orang yang diambil dengan teknik multistage random sampling sebanyak. Ada dua jenis instrumen yang digunakan untuk menjaring data, yaitu tes hasil belajar ips dan angket tipe kepribadian. Sementara itu, teknik analisa data yang digunakan adalah Anava dua jalur yang dilanjutkan dengan uji Tukey.

\section{HASIL DAN PEMBAHASAN}

Berdasarkan uraian tentang temuan penelitian maka secara rinci pembahasan hasil uji hipotesis penelitian ini dapat dijelaskan sebagai berikut.

Pertama, berdasarkan hasil perhitungan ANAVA tampak bahwa nilai $F_{A B}$ sebesar 51,648 yang ternyata lebih besar daripada $F_{\text {tabel }}$ untuk taraf signifikansi 0,05 sebesar 3,94. Jadi, dapat disimpulkan bahwa terdapat interaksi antara model pembelajaran dengan tipe kepribadian dalam pengaruhnya terhadap hasil belajar IPS. Interaksi yang dimaksud dalam hal ini adalah, terdapatnya perbedaan pengaruh model pembelajaran yang diterapkan, yaitu model pembelajaran berbasis masalah berbantuan media audiovisual dan model pembejaran konvensional bila ditinjau dari tipe kepribadian siswa.

Hasil belajar adalah kemampuan yang diperoleh peserta didik setelah melalui kegiatan belajar. Peserta didik yang berhasil dalam belajar ialah yang berhasil mencapai tujuan-tujuan pembelajaran atau tujuan-tujuan instruksional. Salah satu upaya yang dapat dilakukan untuk meningkatkan hasil belajar peserta didik adalah penerapan model pembelajaran. Faktor dominan yang mempengaruhi hasil belajar adalah tidak semata faktor model pembelajaran yang tepat, tetapi ada faktor lain yaitu faktor kepribadian peserta didik itu sendiri. Setiap peserta didik memiliki tipe kepribadian yang tidak sama antara peserta didik satu dengan lainnya.

Kepribadian adalah suatu unsur yang terdapat dalam diri atau individu. Kepribadian ini mencerminkan bagaimana seseorang bertingkah laku dan berpikir. Kepribadian merupakan suatu sistem diri dalam diri individu, sebagai wujud dari pengorganisasian dalam dirinya, yang mana sistem tersebut bersifat dinamis, mengikuti keadaan mental seseorang, dan bersifat unik atau khas. Tipe kepribadian ini dibagi menjadi dua, yaitu: extrovert (cenderung berorientasi keluar) dan introvert (cenderung berorientasi kedalam).

Penggunaan model pembelajaran yang bersifat pasif seperti model pembelajaran konvensional cenderung memberikan pengaruh terhadap peningkatan hasil belajar peserta didik introvert, karena peserta didik introvert cenderung bersifat pasif dan lebih suka bekerja sendirian. Sebaliknya, penggunaan model pembelajaran yang bersifat aktif seperti model pembelajaran problem based learning cenderung berpengaruh terhadap hasil belajar peserta didik extrovert, karena peserta didik extrovert cenderung bersifat aktif dan lebih kooperatif (suka bekerja sama dengan orang lain). Oleh karenanya dengan penggunan model pembelajaran yang tepat dan sesuai dengan tipe kepribadian peserta didik, maka hasil 
belajar peserta didik baik dengan tipe kepribadian introvert dan extrovertakan mengalami peningkatan.

Hal ini sejalan dengan penelitian yang dilakukan oleh Paneo (2007), yang menyebutkan bahwa bagi peserta didik extrovert lebih cenderung dalam kelompok, sebab peserta didik dengan tipe kepribadian extrovert memiliki sifat terbuka, aktif, suka menerima informasi dan koreksi orang lain, suka bertanya dan menanggapi pembicaraan, suka bergaul dan berteman, dapat menerima dan menyesuaikan dalam kelompok, karena dalam kelompok akan diwarnai dengan diskusi dan tanya jawab yang sangat memungkinkan bagi peserta didik yang memiliki tipe kepribadian extrovert menerima dan memahami kesalahankesalahan yang mereka lakukan serta memperbaiki secepatnya kesalahan tersebut. Pada akhirnya akan berdampak positif pada hasil belajarnya. Tentunya ciri-ciri ini sangat sesuai apabila dibelajarkan dengan model pembelajaran yang di dalamnya memberikan kesempatan kepada siswa untuk bekerja dalam kelompok, melakukan diskusi, demokratis, terjadinya tutor teman sebaya. Model pembelajaran yang mengakomodir kegiatan ini adalah model pembelajaran berbasis masalah yang dibantu dengan media audiovisual.

Sedangkan peserta didik yang memiliki tipe kepribadian introvert lebih cenderung tertutup, menyendiri, kurang suka bertanya dan berdebat, kurang bergaul dan berteman serta kurang suka bekerja kelompok. Namun mereka memiliki intelegensi yang relative tinggi, pemikir, mandiri, disiplin, teratur dan konsisten serta percaya pada kemampuan sendiri, ini sangat memungkinkan peserta didik dengan tipe kepribadian introvert untuk lebih berhati-hati dalam menyelesaikan tes atau soal latihan yang diberikan guru, sehingga pada akhirnya akan berdampak positif bagi hasil belajarnya. Ciri-ciri yang dimiliki oleh siswa yang memiliki tipe kepribadian introvert sesua apabila dibelajarkan dengan model pembelajaran konvensioanl.

Model pembelajaran berbasis masalah berbantuan media audiovisual berorientasi pada pembelajaran yang berbasis pada siswa (student centred), suasana belajar yang aktif sehingga terjadi peningkatan pemahaman (bukan ingatan). Siswa belajar atas prakarsa sendiri, peran guru hanya membimbing, mengarahkan sehingga terjadi sharing pengetahuan bukan transfer pengetahuan. Suasana belajar menjadi menyenangkan, kesadaran emosional tidak dalam keadaan tertekan. Dalam suasana seperti itu otak kanan terbuka, daya berpikir intuitif dan holistik akan terangsang untuk bekerja. Hal ini sangat sesuai dengan siswa yang memiliki tipe kepribadian ekstrovert.

Kedua, berdasarkan hasil pengujian secara statistik terbukti bahwa untuk siswa yang memiliki tipe kepribadian ekstrovert, terdapat perbedaan hasil belajar IPS antara siswa yang mengikuti model pembelajaran berbasis masalah berbantuan media audiovisual dan siswa yang mengikuti model pembelajaran konvensional. Siswa yang memiliki tipe kepribadian ekstrovert dan mengikuti model pembelajaran berbasis masalah berbantuan media audiovisual memiliki skor rata-rata hasil belajar IPS sebesar 27,2 lebih tinggi daripada skor rata-rata hasil belajar IPS siswa yang memiliki tipe kepribadian ekstrovert tetapi mengikuti model pembelajaran konvensional sebesar 13,16. Hasil uji Tukey menunjukkan angka Tukey sebesar 9,81 yang ternyata signifikan.

Model pembelajaran berbasis masalah berbantuan media audiovisual berbantuan media audiovisual dalam pembelajaran IPS memberikan ruang yang cukup bagi siswa untuk membangun dan mengembangkan pemahaman konsep IPS secara mendalam, khususnya membangun kompetensi IPS siswa dalam: 1) memecahkan masalah IPS, 2) berargumentasi dan berkomunikasi secara aktif, 3) melakukan penemuan kembali, dan 4) berpikir kreatif yang melibatkan imajinasi, intuisi, penemuan dan generalisasi melalui pemikiran divergen. Jika siswa belajar atas prakarsa sendiri karena guru menaruh kepercayaan terhadap kemampuan anak untuk berpikir dan mengemukakan gagasan baru, dan ketika anak diberi kesempatan untuk bekerja sesuai dengan minat dan kebutuhannya.

Lebih jauh, dalam model pembelajaran berbasis masalah berbantuan media audiovisual siswa diberikan kesempatan seluas-luasnya untuk mengungkapkan gagasangagasannya dan perolehan informasi dalam belajar sesuai dengan kebutuhannya. Dalam model pembelajaran berbasis masalah berbantuan media audiovisual berbantuan media 
audiovisual siswa merupakan objek dan subjek dalam belajar, hal ini sejalan dengan cirri-ciri siswa yang memiliki tipe kepribadian ekstrovert.

Jung (dalam Pervin, 2012) mengatakan bahwa extrovert adalah kepribadian yang lebih dipengaruhi oleh dunia objektif, orientasinya terutama tertuju ke luar. Orang dengan tipe kepribadian extrovert memiliki ciri-ciri yakni sensitive, resah, agresif, bergairah, berubahubah, implusif, optimis, aktif, suka bergaul, ramah, banyak berbicara, responsive, santai, lincah, dan pandai memimpin.

Menurut Hall dan Lindzey (dalam Mularsih, 2010), orang dengan kepribadian extrovert lebih mudah bersosialisasi, senang hura-hura, mempunyai banyak teman, membutuhkan orang untuk diajak bicara, tidak suka membaca atau belajar sendiri, butuh kegembiraan, berani ambil resiko, selalu mempertahankan pendapatnya, bertindak tanpa dipikir dahulu, menuruti kata hati (impulsif), suka melawak, selalu mempunyai jawaban yang segar dan umumnya menyukai perubahan, periang, supel, optimis, dan senang tertawa. Dia lebih suka bergerak dan melakukan kegiatan, cenderung agresif, mudah kehilangan kesabaran. Secara keseluruhan, perasaannya sulit untuk dijaga dan dia tidak selalu dapat dipercaya.

Dengan tipikal seperti itu, hasil belajar IPS peserta didik dengan tipe kepribadian extrovert akan lebih meningkat apabila menggunakan model pembelajaran yang aktif seperti model pembelajaran problem based learning. Karena, model pembelajaran problem based learning menuntut peserta didik untuk menjadi aktif, ditambah lagi pembentukan kelompok belajar yang memerlukan pendekatan sosial baik peserta didik dengan peserta didik maupun peserta didik dengan guru, nampaknya sangat pas bagi tipe kepribadian extrovert. Bahkan dalam menggunakan media pembelajaran seperti media aduaiovisual pun, peserta didik dengan tipe kepribadian extrovert tetap dapat aktif dalam proses belajar mengajar. Hal ini disebabkan karena media aduaiovisual merupakan media yang mengharuskan peserta didik turut aktif dalam proses belajar mengajar. Dengan sifat yang mudah mengekspresikan dirinya, peserta didik dengan tipe kepribadian extrovert cenderung aktif bertanya apabila ada materi yang dirasa kurang mengerti.

Model pembelajaran konvensional adalah suatu model pembelajaran yang biasa digunakan guru dalam membahas suatu materi pembelajaran, dimana model pembelajaran ini lebih menekankan guru sebagai pusat pembelajaran dan sebagai sumber infomasi, sedangkan peserta didik bertindak pasif dengan mendengarkan materi dan mencatat materi saja. Dalam pengajaran tradisional tersebut proses pembelajaran masih sepenuhnya berpusat pada guru (teacher center) yaitu guru menyampaikan materi pelajaran secara verbal (ceramah) dan peserta didik sebatas mendengarkan materi yang diberikan oleh guru, sehingga peserta didik dengan tipe kepribadian extrovert akan cenderung bosan dan malas belajar. Hal ini berpengaruh terhadap hasil belajar IPS peserta didik yang akan cenderung lebih menurun, karena model pembelajaran konvensional merupakan model pembelajaran pasif yang berpusat pada guru.

Hal ini didukung peneliti (Sani) 2014, yang menyebutkan bahwa peserta didik dengan kepribadian extrovert yang diajarkan dengan model pembelajaran kooperatif lebih tinggi dibandingkan dengan peserta didik dengan tipe kepribadian introvert yang diajarkan dengan metode yang sama. Hal ini disebabkan karena model pembelajaran kooperatif menuntut peserta didik untuk memiliki kemampuan yang baik dalam berkomunikasi maupun dalam keterampilan proses kelompok

Ketiga, berdasarkan hasil pengujian secara statistik terbukti bahwa untuk siswa yang memiliki tipe kepribadian introvert, terdapat perbedaan hasil belajar IPS antara siswa yang mengikuti model pembelajaran berbasis masalah berbantuan media audiovisual dan siswa yang mengikuti model pembelajaran konvensional. Siswa yang memiliki tipe kepribadian introvert dan mengikuti model pembelajaran berbasis masalah berbantuan media audiovisual memiliki skor rata-rata hasil belajar IPS sebesar 14,88 lebih rendah daripada skor rata-rata hasil belajar IPS siswa yang memiliki tipe kepribadian introvert dan mengikuti pembelajaran konvensional yaitu sebesar 21,52. Hasil uji Tukey menunjukkan angka Tukey sebesar 4,64 yang ternyata signifikan. 
Pembelajaran konvensional merupakan pembelajaran yang biasa dilakukan guru dalam proses belajar mengajar di dalam kelas. Pembelajarannya lebih berorientasi pada materi yang ada pada buku teks. Pembelajaran seperti ini lebih dikenal dengan gaya bank sehingga gagal menghasilkan peserta didik yang aktif, kreatif dan inovatif. Peserta didik berhasil mengingat jangka pendek tetapi gagal dalam membekali peserta didik dalam memecahkan persoalan dalam kehidupan jangka panjang.

Pembelajaran ini bersumber dari teori stimulus-response. Dalam pembelajaran konvensional, proses belajar mengajar lebih sering diarahkan pada "aliran informasi" atau "transfer" pengetahuan dari guru ke siswa. Penekanan pembelajaran adalah diperolehnya kemampuan mengingat (memorizing) berupa fakta-fakta, sehingga kemampuan yang dimiliki siswa bersifat faktual bukan konseptual.

Sedangkan, problem based learning adalah suatu model pembelajaran yang menggunakan masalah dunia nyata sebagai suatu konteks bagi peserta didik untuk belajar tentang cara berpikir kritis dan keterampilan pemecahan masalah, serta untuk memperoleh pengetahuan dan konsep yang esensial dari materi pelajaran. Model pembelajaran ini menuntut peserta didik untuk terlibat aktif dalam pembelajaran baik mengajukan maupun menyelesaikan permasalahan dunia nyata. Faktor dominan yang mempengaruhi hasil belajar peserta didik tidak semata model pembelajaran yang tepat, akan tetapi ada faktor lain yaitu faktor kepribadian peserta didik itu sendiri. Kepribadian ini dibagi menjadi dua, yaitu: extrovert(berorientasi keluar) dan introvert (berorientasi kedalam). Menurut Eysenck (dalam Pervin, 2012), gambaran individu yang termasuk kecenderungan introvert adalah memperlihatkan kecenderungan bersifat murung, cemas, kaku, bijaksana, pesimis, pendiam, sulit bergaul, tenang, pasif, hati-hati, tenang dan dapat dipercaya. Secara singkat individu introvert adalah individu yang cenderung menarik diri dari kontak sosial. la melakukan sesuatu menurut caranya sendiri, menutup diri terhadap pengaruh dunia luar.

Hall dan Lindzey (dalam Mularsih, 2010) menambahkan bahwa karakteristik introvert adalah pemalu, introspektif, menyukai buku-buku daripada manusia, suka menyendiri dan tidak ramah kecuali pada teman dekatnya. Dia cenderung merencanakan segala sesuatu dengan berhati-hati, sebelum melangkah dan tidak mudah percaya kata hati. Dia tidak menyukai keramaian, menanggapi semua masalah dalam hidup dengan serius, dan menyukai kehidupan yang teratur. Dia selalu menyembunyikan perasaan, jarang bertindak agresif, dan tidak mudah kehilangan kesabaran. Dia orang yang dapat dipercaya dan agak pesimis.

Dengan tipikal seperti itu, hasil belajar peserta didik dengan tipe kepribadian introvert lebih menurun apabila menggunakan model pembelajaran yang aktif seperti model pembelajaran problem based learning. Karena, model pembelajaran problem based learning menuntut peserta didik untuk menjadi aktif, ditambah lagi pembentukan kelompok belajar yang memerlukan pendekatan sosial baik peserta didik dengan peserta didik maupun peserta didik dengan guru, sangat berbeda dengan tipe kepribadian introvert yang cenderung menutup diri. Bahkan Dalam menggunakan media aduaiovisual, peserta didik dengan tipe kepribadian introvert tetap tidak aktif dalam proses belajar mengajar. Hal ini disebabkan karena media aduaiovisual merupakan media pembelajaran yang mengharuskan peserta didik turut aktif dalam proses belajar mengajar. Dengan sifat yang sulit mengekspresikan dirinya, peserta didik dengan tipe kepribadian introvert cenderung tidak aktif bahkan malas bertanya apabila ada materi yang dirasa kurang mengerti dan mereka cenderung menjadi sielent reader tanpa bersosialisasi dengan teman lainnya.

Model pembelajaran konvensional adalah suatu model pembelajaran yang biasa digunakan guru dalam membahas suatu materi pembelajaran, dimana model pembelajaran ini lebih menekankan guru sebagai pusat pembelajaran dan sebagai sumber infomasi, sedangkan peserta didik bertindak pasif dengan mendengarkan materi dan mencatat materi saja. Dalam pengajaran tradisional tersebut proses pembelajaran masih sepenuhnya berpusat pada guru (teacher center) yaitu guru menyampaikan materi pelajaran secara verbal (ceramah) dan peserta didik sebatas mendengarkan materi yang diberikan oleh guru, sehingga hasil belajar peserta didik dengan tipe kepribadian introvert akan cenderung lebih meningkat apabila menggunakan model pembelajaran konvensional, karena peserta didik 
dengan tipe kepribadian introvert lebih nyaman mendengarkan pembelajaran secara satu arah (pasif) dibandingkan harus turut aktif dalam pembelajaran karena mereka cenderung sulit bergaul.

Hal ini didukung pula dengan penelitian yang dilakukan oleh Sari (2012) yang menyebutkan bahwa peserta didik dengan tipe kepribadian introvert menunjukkan hasil belajar yang lebih tinggi bila diajarkan dengan model pembelajaran langsung. Hal ini sangat beralasan karena model pembelajaran ini berpusat pada guru. Sistem pengelolaan pembelajaran yang dilakukan oleh guru harus menjamin terjadinya keterlibatan peserta didik, terutama melalui memperhatikan, mendengarkan dan resitasi (tanya jawab) yang terencana. Model pembelajaran ini sesuai bagi peserta didik yang kurang memiliki kemampuan untuk mengutarakan ide dan tanggapan tentang materi pelajaran, karena guru akan memberikan informasi kepada peserta didik agar tujuan pembelajaran dapat tercapai dan materi pembelajaran dapat dikuasi oleh peserta didik. Model pembelajaran langsung mendukung peserta didik yang memiliki kepribadian introvert untuk dapat menguasai suatu materi dengan baik tanpa memaksa mereka untuk melakukan komunikasi yang intens kepada sesama peserta didik maupun guru.

\section{SIMPULAN DAN SARAN}

Berdasarkan hasil pengujian hipotesis seperti disajikan pada Bab IV, maka dalam penelitian ini diperoleh simpulan sebagai berikut. Penelitian ini menemukan bahwa terdapat interaksi antra model pembelajaran yang diterapkan dengan tipe kepribadian dalam pengaruhnya terhadap hasil belajar IPS. Lebih jauh dapat dilihat bahwa apabila dalam pelaksanaan pembelajaran siswa diklasifikasikan menurut tipe kepribadian, maka ditemukan bahwa model pembelajaran berbasis masalah berbantuan media audio visual dan model pembelajaran konvensional memberikan pengaruh yang berlawanan. Bagi kelompok siswa yang memiliki tipe kepribadian ekstrovert, hasil belajar IPS siswa yang mengikuti model pembelajaran berbasis masalah berbantuan media audiovisual lebih baik daripada hasil belajar IPS siswa yang mengikuti model pembelajaran konvensional. Sebaliknya, bagi kelompok siswa yang memiliki tipe kepribadian introvert, hasil belajar IPS siswa yang mengikuti model pembelajaran konvensional baik daripada hasil belajar IPS siswa yang mengikuti model pembelajaran berbasis masalah berbantuan media audiovisual.

Berdasarkan uraian di atas, kesimpulan dalam penelitian ini adalah bahwa model pembelajaran berbasis masalah berbantuan media audiovisual lebih unggul dibandingkan model pembelajaran konvensional dalam hal hasil belajar IPS. Agar diperoleh hasil yang maksimal, dalam pembelajaran IPS, tipe kepribadian siswa harus dipertimbangkan.

Berkenaan dengan hasil penelitian yang diperoleh, disarankan agar model pembelajaran berbasis masalah berbantuan media audiovisual perlu dikenalkan dan dikembangkan lebih lanjut kepada para guru, siswa dan praktisi pendidikan lainnya sebagai salah satu alternatif pembelajaran.

\section{DAFTAR RUJUKAN}

Harjanto. 2005. Perencanaan Pembelajaran. Jakarta: Rineka Cipta.

Lestari, Ni Nyoman Sri. 2015. Pengaruh Model Pembelajaran Berbasis Masalah (Problem Based Learning) dan Motivasi Belajar Terhadap Prestasi Belajar Fisika Bagi Siswa Kelas VII SMP. e-jurnal. Pascasarjana Undiksha. Diakses Tanggal 28 Juli 2017.

Mularsih, Heni. 2010. Strategi Pembelajaran, Tipe Kepribadian, dan Hasil Belajar Bahasa Indonesia Pada Siswa Sekolah Menengah Pertama. Makara, Sosial Humaniora Vol. 14 No. 1 Tahun 2010. Depok: Universitas Indonesia.

Pervin, Lawrence A., Cervone, Daniel, dan John, Oliver P. 2012. Psikologi Kepribadian Teoridan Penelitian. Jakarta: Prenada Media Group. 
Rasmianti, Ike. Raga, Gede., Agustiana, I. G. A. Tri. 2013. Pengaruh Metode Pembelajaran Problem Posing Terhadap Kemampuan Pemecahan Masalah Matematika Siswa Kelas IV SD Gugus VI Kecamatan Banjar. Jurnal Jurusan Pendidikan Guru Sekolah Dasar Vol. 1 Tahun 2013. Singaraja: Undiksha.

Sani, Abdullah Ridwan. 2014. Pembelajaran Saintifik Untuk Implementasi Kurikulum 2013. Jakarta: PT. Bumi Aksara.

Sanjaya, Wina. (2008) Strategi Pembelajaran Berorientasi Standar Proses Pendidikan. Jakarta : Kencana Prenada Media Grouf.

Supriadi, Sujana, dan Wiarta. 2013. Model Pembelajaran Problem Based Learning (PBL) Berbantuan Media Audiovisual Berpengaruh Terhadap Hasil Belajar IPS Siswa Kelas IV Sd Gugus Ubud Gianyar. e-jurnal. Undiksha. Diakses Tanggal 28 Juli 2017.

Ulya, Nur Maziyah. 2016. Pengaruh Metode Pembelajaran dan TipeKepribadian Terhadap Hasil Belajar Bahasa Arab (Studi Eksprerimen Pada MAN 1 Semarang). Jurnal Pendidikan Islam Vol. 10 Nomor 1. Semarang: UIN Walisongo Semarang. 